\title{
Nebuliser performance, pharmacokinetics, airways and systemic effects of salbutamol given via a novel nebuliser delivery system ("Ventstream")
}

\author{
Donald M Newnham, Brian J Lipworth
}

\begin{abstract}
Background - Currently available nebulisers are inefficient and show variable aerosol deposition in the lung owing to the differences in the particle size generated. The aim of this study was to compare systemic absorption and bronchodilator effects of salbutamol given via a novel ("Ventstream") and a conventional ("Hudson Updraft II") nebuliser system, having initially evaluated the performance of both nebulisers in vitro. The "Ventstream" nebuliser uses a one way valve system to provide an additional inspiratory side flow to match aerosol delivery with tidal volume.

Methods - Nebuliser output and particle distribution from 10 Ventstream and 10 Hudson nebulisers were compared in vitro. Eight asthmatic patients, FEV $^{1}$ $55(2) \%$ predicted, were then randomised to receive salbutamol via Ventstream or Hudson nebulisers on separate days. On each day cumulative doses of inhaled salbutamol were given: $1.25 \mathrm{mg}, 2.5 \mathrm{mg}$ $(1.25+1.25 \mathrm{mg})$, and $5.0 \mathrm{mg}(2.5+2.5 \mathrm{mg})$. Airways responses, systemic responses, and plasma salbutamol concentrations were measured at each dose and for up to 240 minutes after the final dose.
\end{abstract}

Results - The in vitro comparison showed a greater respirable fraction with a higher percentage volume of particles $<5 \mu \mathrm{m}$ in diameter using Ventstream than Hudson nebulisers (mean (95\% CI) for difference): $25 \cdot 4 \%(95 \%$ CI $22 \cdot 4 \%$ to $28 \cdot 3 \%)$, and a higher aerosol rate of output: $0.08 \mathrm{~g} / \mathrm{min}$ (95\% CI 0.05 to $0.11 \mathrm{~g} / \mathrm{min})$. At the $5.0 \mathrm{mg}$ dose the Ventstream produced a twofold greater concentration of plasma salbutamol than the Hudson nebuliser $\left(\right.$ AUC $\left._{0-240}\right): 392 \cdot 1 \mathrm{ng} / \mathrm{ml} . \mathrm{min}$ (95\% CI 240.6 to $543.6 \mathrm{ng} / \mathrm{ml} . \mathrm{min})$. There was a higher AUC $_{0-240}$ for PEFR with the Ventstream than with the Hudson nebuliser: $74 \cdot 161 \times 10^{2}\left(95 \%\right.$ CI 39.50 to $108.821 \times 10^{2}$. For FEV $_{1}$ and $F E V_{25-75}$ there was a difference in the peak response between the $5.0 \mathrm{mg}$ and $2.5 \mathrm{mg}$ doses with the Ventstream only. Extrapulmonary $\beta_{2}$ responses were greater with the Ventstream than with the Hudson at $2.5 \mathrm{mg}$ and $5.0 \mathrm{mg}$ doses, although the differences did not appear to be clinically relevant.

Conclusions - The Ventstream produced a twofold increase in the delivery of salbutamol to the lung compared with the Hudson nebuliser, and there was an associated increase in systemic $\beta_{2}$ responses with an improvement in some parameters of bronchodilator efficacy. As a consequence of improved delivery with the Ventstream, it may be possible to halve the drug dose to produce similar bronchodilator efficacy at reduced cost. Further studies are required to evaluate the value of the Ventstream for delivery of nebulised antibiotics and corticosteroids.

(Thorax 1994;49:762-770)

Currently available nebulisers lack precision in that a substantial proportion of the inhaled dose is lost to the atmosphere. ${ }^{1}$ Furthermore, significant differences in lung deposition of aerosol can occur with commonly used nebuliser delivery systems as a result of variability in the particle size generated. ${ }^{23}$ Nebulisers remain widely accepted as the delivery system of choice, however, in those patients with chronic asthma or chronic obstructive pulmonary disease (COPD) who require high dose inhaled bronchodilator therapy. ${ }^{45}$ In contrast to metered dose and dry powder devices, there are relatively few available data regarding doseresponse relationships for nebulised bronchodilator drugs in either asthma or $\mathrm{COPD}^{6}$ despite concerns regarding the systemic adverse effects of high dose inhaled $\beta_{2}$ agonists. $^{7}$

In this respect a novel nebuliser delivery system ("Ventstream", Medic-Aid, Pagham, UK) has been developed which improves delivery of inhaled drugs to the lungs using a low resistance one way valve system which allows a side flow in addition to the $61 / \mathrm{min}$ from the compressor source (fig 1A). This works by using the patient's own inspiration to boost the nebuliser performance during this phase of the respiratory cycle so that aerosol production matches the patient's tidal volume (fig 1B). Furthermore, on expiration the one way valves within the system only allow aerosol production to be generated from the compressor gas source which minimises drug wastage. It is not known, however, whether improved drug delivery with the Ventstream will alter the dose-response relations of inhaled $\beta_{2}$ agonists in terms of bronchodilator and systemic $\beta_{2}$ responses. The aim of the present study was therefore to com- 
A

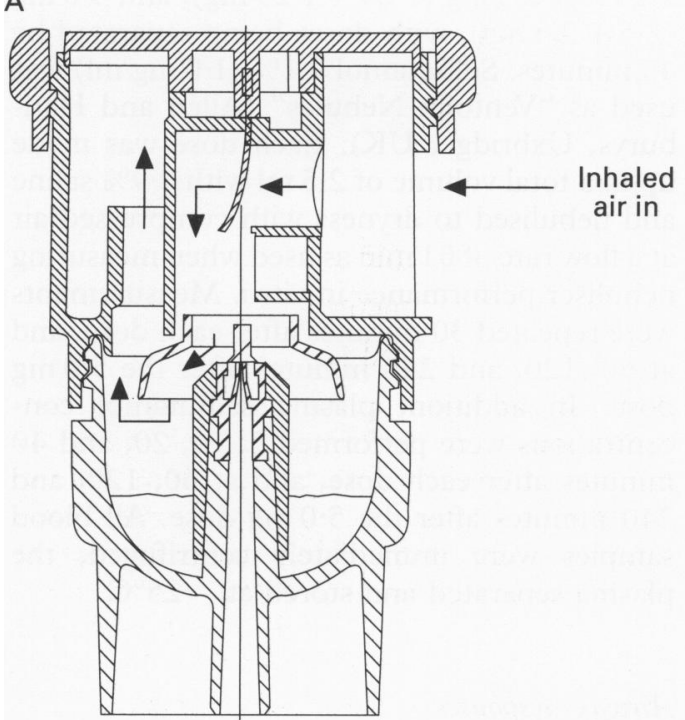

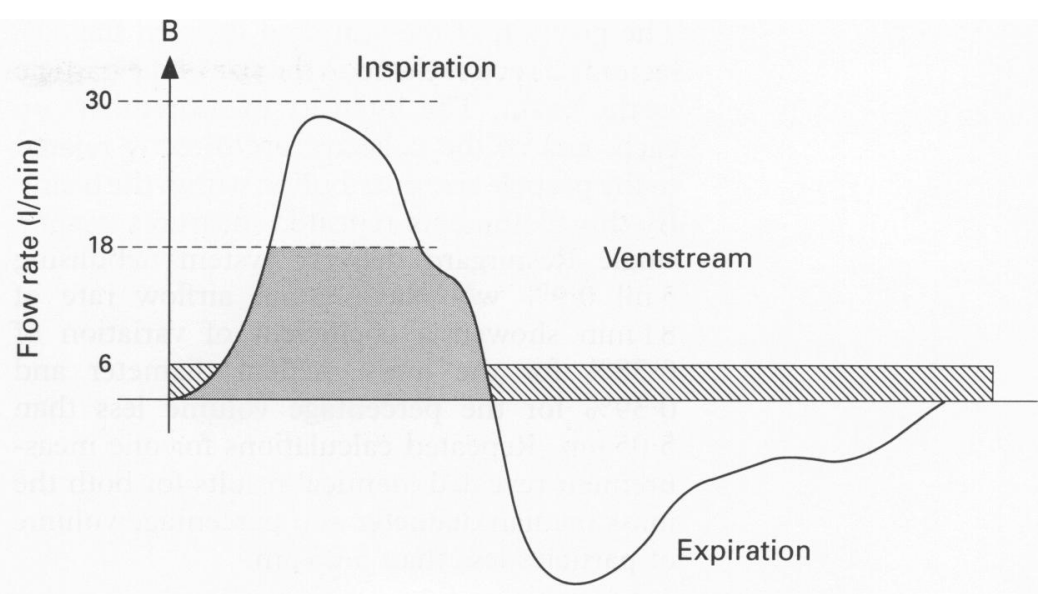

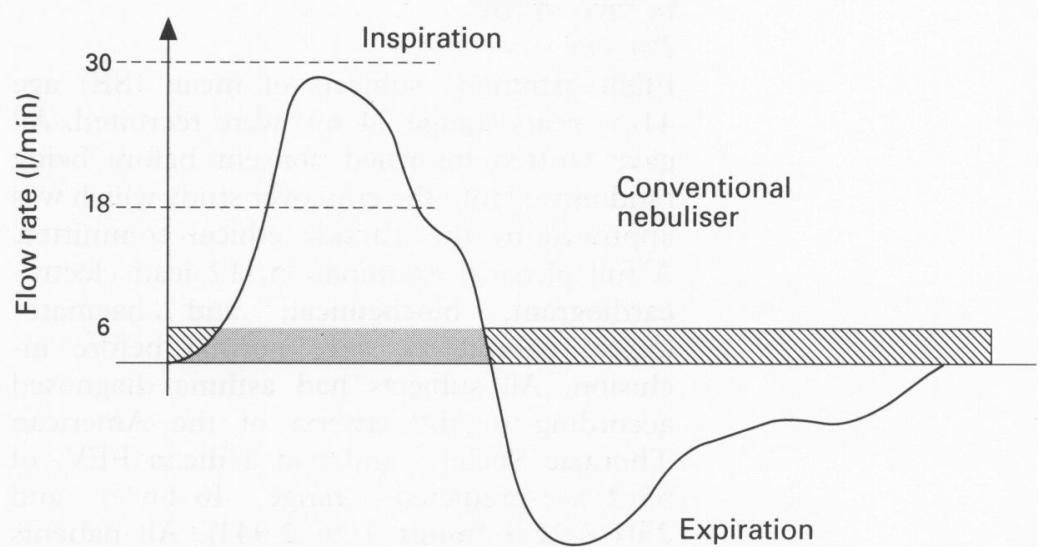

Figure 1 (A) Cross sectional view of Ventstream nebuliser showing the direction of inspiratory flow from the side port via the one way valve through the closed system of the nebuliser. (B) Schematic diagram illustrating in vitro operating flow rates for Ventstream and conventional Hudson nebuliser during inspiration and expiration. Both nebulisers were run at a flow rate of $6 \mathrm{l} / \mathrm{min}$. In addition, a low resistance one way valve allows additional side flow of $12 \mathrm{l} / \mathrm{min}$ to be generated during inspiration which matches the patient's tidal volume. This, in turn, boosts aerosol output during inspiration but minimises wastage during expiration. The shaded area represents drug delivery to the lung during inspiration, and the hatched area represents drug wastage during expiration.

pare the systemic absorption and bronchodilator effects of equivalent doses of salbutamol given via the Ventstream with a conventional nebuliser system ("Hudson Updraft II", Hudson Respiratory Care Inc, California, USA) having initially evaluated the performance of both delivery systems in vitro.

\section{Methods}

IN VITRO STUDY

Before commencing the in vivo study 10 nebulisers of each type were selected at random and their performances evaluated in terms of aerosol output and particle size in order to select a representative unit of each type for use in the in vivo study. All were operated from compressed air at a flow rate of $6 \mathrm{l} / \mathrm{min}$ which meets the manufacturers' recommendations for both nebuliser systems. In addition the Ventstream was tested with an additional side flow of $12 \mathrm{l} / \mathrm{min}$, representing a total flow rate of $181 / \mathrm{min}$. Compressed dry air was used to control evaporative changes due to ambient relative humidity and both nebulisers were operated for a period of six seconds to determine weight loss and solution output. Respective values were then factored by 10 in order to give a total output rate in $\mathrm{g} / \mathrm{min}$. From the results two Ventstream nebulisers and two
Hudson nebulisers were selected as giving typical performance (closest to the mean) and these were supplied unmarked for use in the in vivo study.

\section{Rate of output}

Nebuliser output was evaluated both by weight loss (weighing the nebuliser unit before and after use) under defined operating conditions for flow rate, temperature and humidity, and by direct analysis of solution output using the technique of fluoride ion analysis as described by Dennis et al. ${ }^{8}$ The latter method is more accurate than evaluating weight loss alone as it determines only the solution output and not the vapour evaporation which also contributes to weight loss during nebulisation and therefore represents the true nebuliser output excluding evaporation. The error of fluoride determination was within $\pm 2 \%$.

\section{Particle size}

Particle size and particle size distribution were determined by laser defraction using a Malvern Mastersizer optical particle size analyser (Malvern Instruments, Malvern, UK). The laser is scattered by the particles and the scattered light collected by a lens and directed onto a collector. 
The position of the scattered light on the collector is directly related to the size of the particle in the beam. The intensity measurements on each area of the collector are directly related to the particle size distribution within the beam. By this method six repeated measures using a single Respirgard delivery system nebulising $5 \mathrm{ml} 0.9 \% \mathrm{w} / \mathrm{v} \mathrm{NaCl}$ at an airflow rate of $8 \mathrm{l} / \mathrm{min}$ showed a coefficient of variation of $0.38 \%$ for the mass median diameter and $0.39 \%$ for the percentage volume less than $5.05 \mu \mathrm{m}$. Repeated calculations for one measurement revealed identical results for both the mass median diameter and percentage volume of particles less than $5.05 \mu \mathrm{m}$.

\section{IN VIVO STUDY}

\section{Patients}

Eight asthmatic subjects of mean (SE) age 41(5) years (range 24-69) were recruited. All gave written informed consent before being randomised into the crossover study which was approved by the Tayside ethical committee. A full physical examination, 12 lead electrocardiogram, biochemical, and haematological parameters were normal before inclusion. All subjects had asthma diagnosed according to the criteria of the American Thoracic Society ${ }^{9}$ and had a mean $\mathrm{FEV}_{1}$ of $55(2) \%$ predicted (range 46-66\%) and $2 \cdot 01(0 \cdot 22) 1$ (range $1 \cdot 26-2.941)$. All patients were required to have shown $>15 \%$ reversibility to inhaled salbutamol $200 \mu \mathrm{g}$ given by metered dose inhaler. Seven subjects were inhaling beclomethasone dipropionate in daily doses of $400 \mu \mathrm{g}$ (one patient), $600 \mu \mathrm{g}$ (two patients), $800 \mu \mathrm{g}$ (one patient), $1000 \mu \mathrm{g}$ (one patient), and $2000 \mu \mathrm{g}$ (two patients). All subjects were inhaling salbutamol as required at a dose less than $600 \mu \mathrm{g}$ per day. In addition, one subject was inhaling nedocromil sodium $8 \mathrm{mg}$ per day, oxitropium bromide $200 \mu \mathrm{g}$ twice daily, and salmeterol $100 \mu \mathrm{g}$ twice daily. Two subjects were taking oral theophylline $(225-675 \mathrm{mg}$ daily), none had received oral prednisolone for at least three months, and none had had a recent exacerbation of their asthma. All subjects were non-smokers.

\section{Protocol}

Subjects attended the laboratory on two separate days, seven days apart, having withheld inhaled bronchodilator therapy for at least 12 hours, and oral theophylline preparations and salmeterol for 48 hours. The baseline $\mathrm{FEV}_{1}$ values on both study days were required to be within $15 \%$ of each other. A cannula was inserted and kept patent with bolus injections of heparinised saline. Cannula dead space of $2 \mathrm{ml}$ was withdrawn before the collection of each blood sample. After an initial 30 minute rest period the following baseline measurements were performed over a five minute period: forced expiratory volume in one second $\left(F E V_{1}\right)$, forced vital capacity (FVC), forced expiratory flow rate at $25-75 \%$ of vital capacity $\left(\mathrm{FEF}_{25-75}\right)$, peak expiratory flow rate (PEFR), serum potassium concentration, heart rate, finger tremor, ECG parameters ( $T$ wave, Q-Tc), and plasma salbutamol concentration. A dose-response curve was then constructed to inhaled salbutamol at cumulative doses of $1.25 \mathrm{mg}, 2.5 \mathrm{mg}(1.25+1.25 \mathrm{mg})$, and $5.0 \mathrm{mg}$ $(2 \cdot 5+2.5 \mathrm{mg})$, with doses being separated by 45 minutes. Salbutamol $0 \cdot 1 \%(1.0 \mathrm{mg} / \mathrm{ml})$ was used as "Ventolin Nebules" (Allen and Hanburys, Uxbridge, UK). Each dose was made up to a total volume of $2.5 \mathrm{ml}$ with $0.9 \%$ saline and nebulised to dryness with compressed air at a flow rate of $6 \mathrm{l} / \mathrm{min}$ as used when measuring nebuliser performance in vitro. Measurements were repeated 30 minutes after each dose, and at 60,120 , and 240 minutes after the $5.0 \mathrm{mg}$ dose. In addition, plasma salbutamol concentrations were performed $5,10,20$, and 40 minutes after each dose, and at 60,120, and 240 minutes after the $5.0 \mathrm{mg}$ dose. All blood samples were immediately centrifuged, the plasma separated and stored at $-25^{\circ} \mathrm{C}$.

\section{Airways responses}

Measurements of airways responses were performed according to American Thoracic Society criteria ${ }^{10}$ using a Vitalograph compact spirometer (Vitalograph Ltd, Buckingham, UK) with a pneumotachograph head and pressure transducer, and online computer assisted determination of $\mathrm{FEV}_{1}, \mathrm{FVC}, \mathrm{FEF}_{25-75}$, and PEFR. Forced expiratory manoeuvres were performed from total lung capacity to residual volume. The best $\mathrm{FEV}_{1}$ and FVC values were taken from three consistent measurements, with the best $\mathrm{FEF}_{25-75}$ and PEFR values being taken from the best test result of three consistent forced expiratory curves. ${ }^{10} \mathrm{~A}$ coefficient of variation of less than $3 \%$ for three reproducible measurements of $\mathrm{FEV}_{1}$ and $5 \%$ for FVC and $\mathrm{FEF}_{25-75}$ was considered as being acceptable.

\section{Systemic responses}

All biochemical analyses were performed in batches at the end of the study and samples were assayed in duplicate. Serum potassium concentrations were measured by flame photometry (IL943 analyser, Instrumentation Laboratory Ltd, Warrington, UK). Coefficients of variability within and between assays were $0.38 \%$ and $0.44 \%$ respectively. The normal reference range for our laboratory is 3.5-5.0 mmol/1.

Plasma salbutamol concentrations were measured using a previously validated HPLC assay. ${ }^{11}$ Coefficients of variability within and between assays were $4.0 \%$ and $6.7 \%$ respectively at a concentration of $7 \cdot 5 \mathrm{ng} / \mathrm{ml}$. The limit of detection for the assay was $1 \cdot 0 \mathrm{ng} / \mathrm{ml}$.

The electrocardiogram was recorded on standard lead II using a Hewlett Packard (Palo Alto, California, USA) monitor and printer with paper speed set at $50 \mathrm{~mm} / \mathrm{s}$ and $0.5 \mathrm{mV} / \mathrm{cm}$ gain. The following parameters were measured from the mean of five consecutive complexes: $\mathrm{R}-\mathrm{R}$ interval (s), Q-T interval ( $\mathrm{ms}$ ), and $\mathrm{T}$ wave amplitude $(\mathrm{mV})$. The $\mathrm{Q}-\mathrm{T}$ interval was measured using the method described by 
Table 1 Pharmacokinetic parameters

\begin{tabular}{|c|c|c|c|}
\hline & $\begin{array}{l}\text { Mean }(95 \% \mathrm{CI}) \\
C_{\max }(\mathrm{ng} / \mathrm{ml})\end{array}$ & $\begin{array}{l}\text { Median (range) } \\
t_{\max }(\min )\end{array}$ & $\begin{array}{l}\text { Mean }(95 \% \text { CI }) \\
A U C_{0-2+0}(\mathrm{ng} / \mathrm{ml} . \mathrm{min})\end{array}$ \\
\hline \multicolumn{4}{|l|}{$1.25 \mathrm{mg}$} \\
\hline Ventstream & $1.53(1.16 \text { to } 1.89)^{* *}$ & $10(5-40)$ & \\
\hline Hudson & $0.62(0.26$ to 0.99$)$ & $10(5-10)$ & \\
\hline $2.5 \mathrm{mg}$ & & & \\
\hline Ventstream & $2.61(2.31 \text { to } 2.92)^{* * *}$ & $5(5-20)$ & \\
\hline Hudson & $1.49(1.19$ to $1 \cdot 79)$ & $10(5-10)$ & \\
\hline \multicolumn{4}{|l|}{$5.0 \mathrm{mg}$} \\
\hline Ventstream & $4.59(3.86 \text { to } 5.31)^{* *}$ & $10(5-20)$ & $789 \cdot 9(682 \cdot 9 \text { to } 897 \cdot 0)^{* * *}$ \\
\hline Hudson & $2.31(1.59$ to 3.04$)$ & $5(5-20)$ & $397 \cdot 9(290 \cdot 8$ to $505 \cdot 0)$ \\
\hline
\end{tabular}
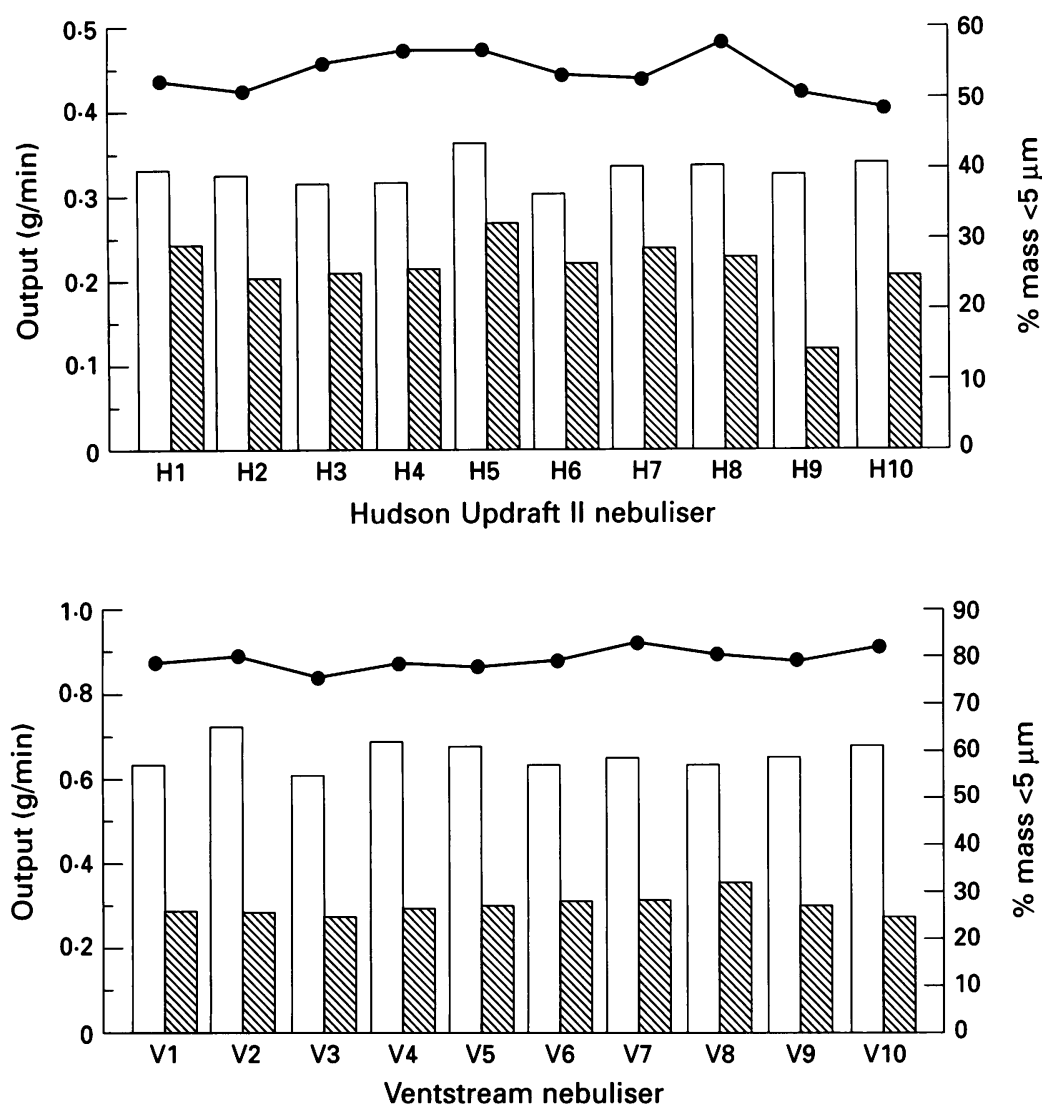

Figure 2 Total nebulised rate of weight loss (including evaporation loss) ( $\square$ ), rate of

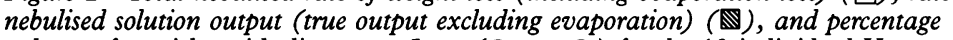
volume of particles with diameter $<5 \mu \mathrm{m}$ (1) for the 10 individual Ventstream and Hudson nebulisers measured in vitro. Values are shown as absolutes. Nebulisers H3, H4 and V9, V1O were used in the in vivo study.
Shamroth ${ }^{12}$ to account for the presence of $U$ waves. The formula of Bazett ${ }^{13}$ was used to correct the Q-T interval for heart rate $(\mathrm{Q}-\mathrm{Tc})$. The heart rate was calculated from the $R-R$ interval.

Finger tremor was recorded by a previously validated method $^{14}$ using an accelerometer transducer (Entran Ltd, Ealing, UK); five recordings were taken and stored on computer disk for subsequent spectral analysis of total tremor power $>2 \mathrm{~Hz}$ (units of $\mathrm{mg}^{2} / \mathrm{s}$ ) using computer assisted autocovariance. The mean of the three lowest consistent readings was used. Since tremor power is not normally distributed, log transformation was used in the analysis.

\section{STATISTICAL ANALYSIS}

All data were analysed using a Statgraphics Software Package (STSC Software Publishing Group, Bethesda, USA). The serum potassium concentration was chosen before the study as the primary endpoint for the analysis with the use of eight subjects being sufficient to detect a $0.3 \mathrm{mmol} / 1$ difference between the two nebulisers with $80 \%$ power $(\beta$ error $=0 \cdot 20)$, with an alpha error set at 0.05 (two tailed).

Comparisons between the two nebulisers (treatments) were made by multifactorial analysis of variance (ANOVA) using subjects, treatment doses and time as within factors for the analysis, and Bonferroni multiple range testing. The differences between the two nebulisers were calculated as $95 \%$ confidence intervals. A probability value of $\mathrm{p}<0.05$ (two tailed) was considered to be significant. Absolute values were used in the analysis when comparing the two nebulisers at baseline and at each dose level ( 30 minutes after dose). In addition to analysing the peak response 30 minutes after dose, the area under the response-time profile from 0-240 minutes ( $\left.\mathrm{AUC}_{0-240}\right)$ after the $5.0 \mathrm{mg}$ dose was compared. Values, as change from baseline (delta), were used to compare doses for each nebuliser (Ventstream or Hudson) in order to evaluate dose-response relations.

For pharmacokinetic parameters comparisons were made between the two nebulisers at each dose level. In addition, derived phar-
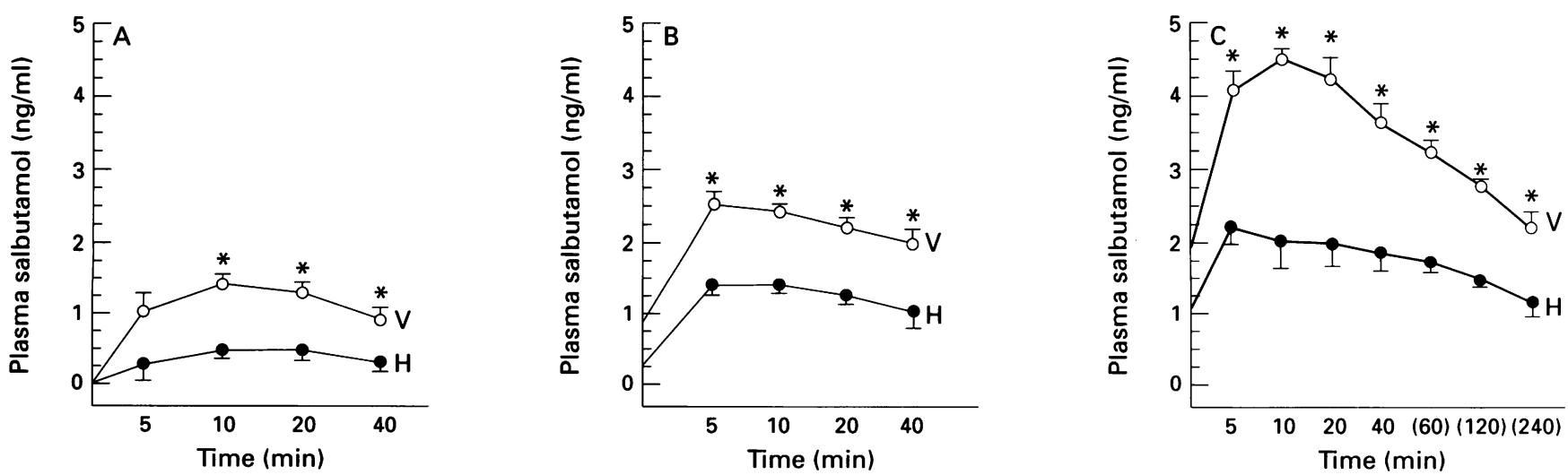

Figure 3 Plasma concentration profiles for salbutamol before and 5, 10, 20, and 40 minutes after inhalation of (A) $1 \cdot 25 \mathrm{mg}$, (B) $2 \cdot 5 \mathrm{mg}$, and (C) $5.0 \mathrm{mg}$ doses, and at 60,120, and 240 minutes after the final dose for the Ventstream (O) and Hudson (O) nebulisers. Values are shown as means and $(S E) .{ }^{*} p<0.05$ for the difference between the Ventstream and Hudson nebulisers. 

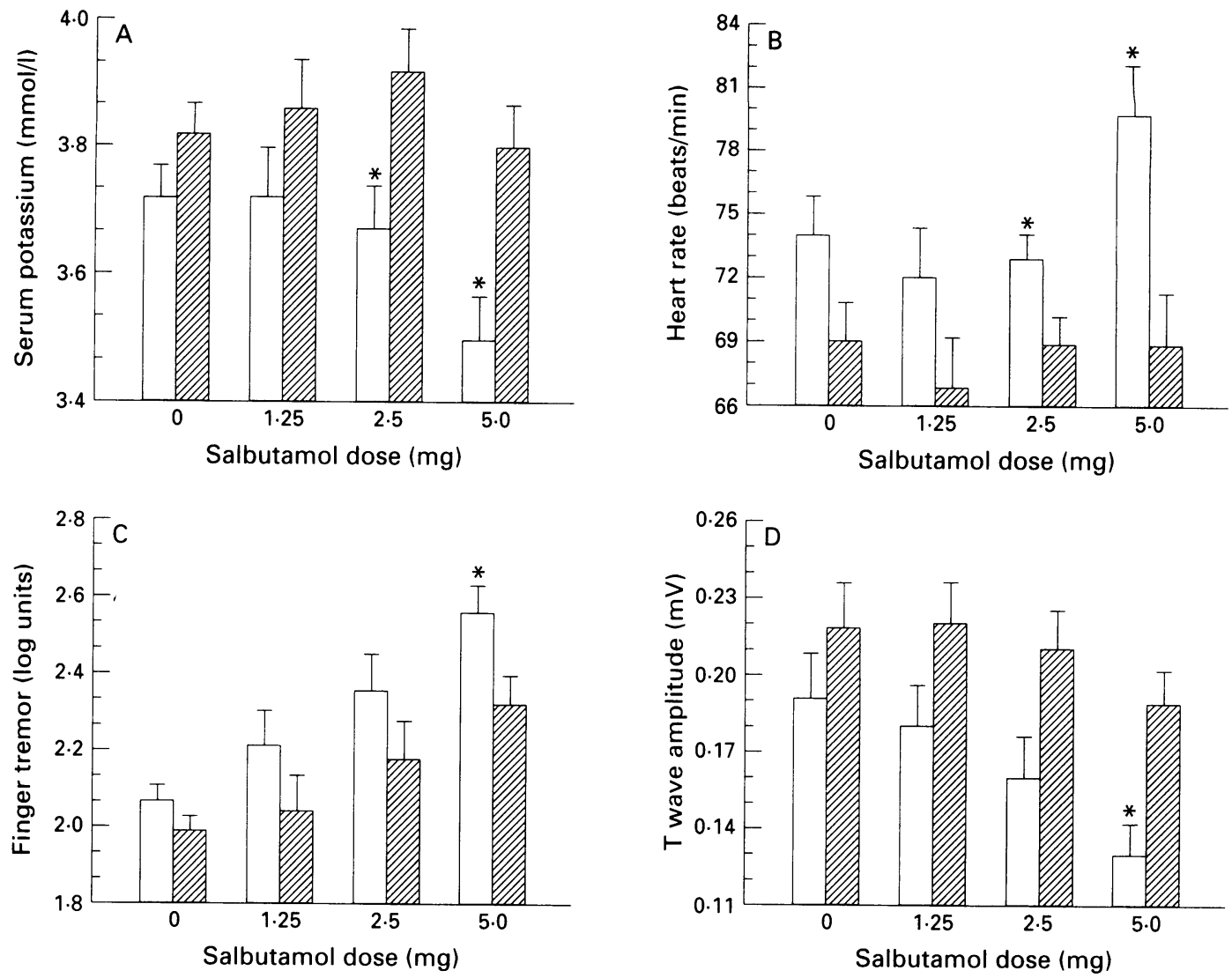

Figure 4 Responses in $(A)$ serum potassium, (B) heart rate, $(C)$ finger tremor, and (D) $T$ wave amplitude to nebulised salbutamol given via the Ventstream ( $\square$ ) and Hudson (ख) nebulisers at baseline (0) and 30 minutes after doses of $1.25 \mathrm{mg}, 2.5 \mathrm{mg}$ and $5.0 \mathrm{mg}$. Values (as absolutes) are shown as means (SE). Asterisks denote a significant $(p<0.05)$ difference between the Ventstream and Hudson nebulisers at each dose.
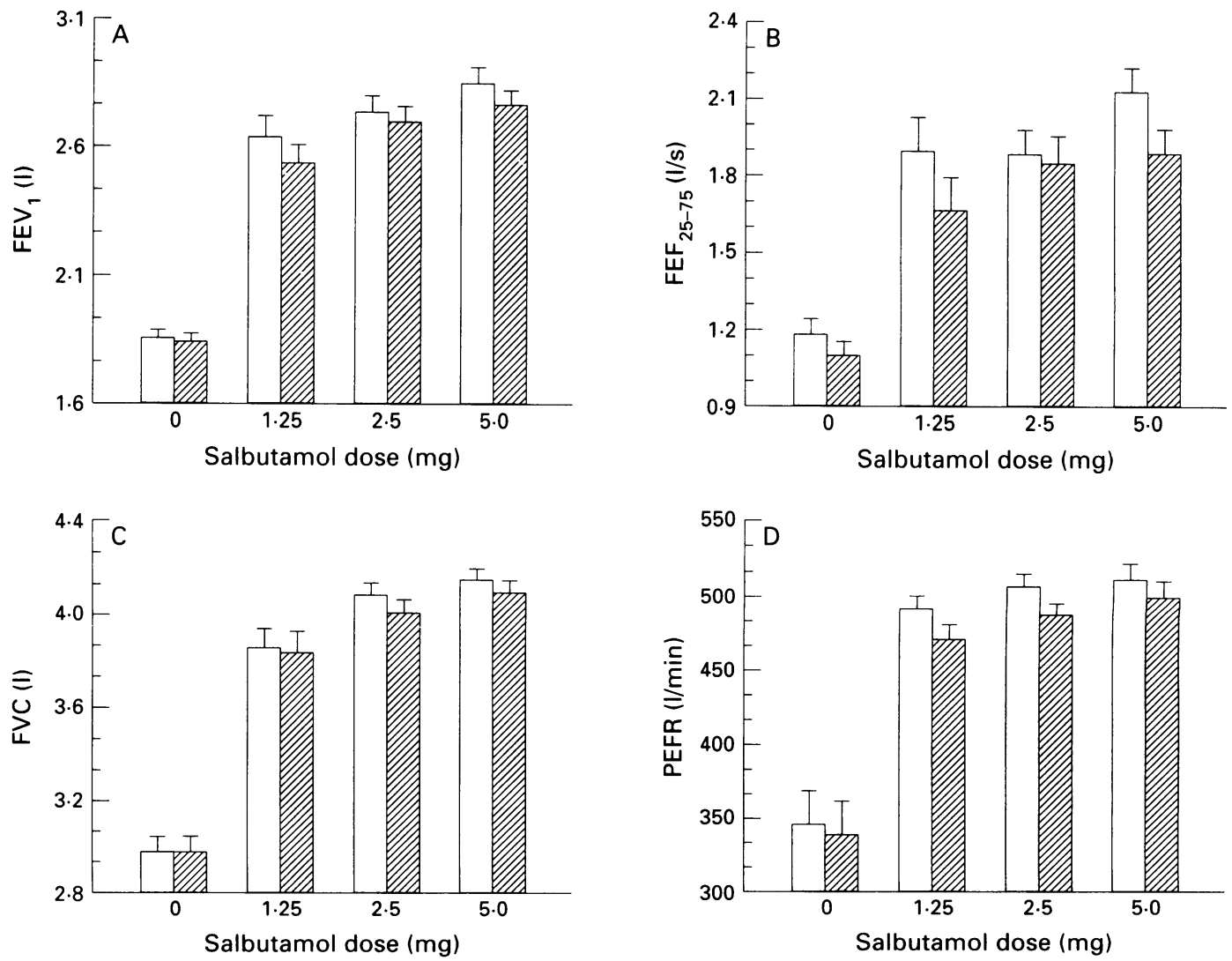

Figure 5 Bronchodilator responses to salbutamol given via the Ventstream ( $\square$ ) and Hudson (囵) nebulisers as in fig 4. No significant differences were seen between the two nebulisers for any of the parameters measured. 
macokinetic parameters of the maximum salbutamol concentration achieved $\left(\mathrm{C}_{\max }\right)$, and the time to attain maximum concentration $\left(t_{\max }\right)$ were calculated at each dose, as well as the area under the concentration-time curve for 0-240 minutes $\left(\mathrm{AUC}_{0-240}\right)$ after the $5.0 \mathrm{mg}$ dose. $\mathrm{C}_{\max }$ and $\mathrm{AUC}_{0-240}$ were compared by two-way ANOVA, and $t_{\max }$ was compared by non-parametric Friedman's ANOVA. In vitro data for the Ventstream and Hudson delivery systems were compared by two way ANOVA with values expressed as means and $95 \% \mathrm{CI}$ for the difference.

\section{Results}

NEBULISER PERFORMANCE (fig 2)

In vitro the Ventstream delivery system produced a significantly $(p<0.005)$ greater aerosol output rate, both in terms of weight loss $(95 \%$ CI for difference): $0.33(0.30$ to 0.36$) \mathrm{g} / \mathrm{min}$ and rate of solution output: $0.08(0.05$ to 0.11$)$ $\mathrm{g} / \mathrm{min}$ when compared with the Hudson. The Ventstream also reduced the particle size as shown by a significantly lower mass median diameter: $1.54(1.29$ to 1.79$) \mu \mathrm{m}(\mathrm{p}<0.005)$, and a significantly higher percentage volume of particles $<5 \mu \mathrm{m}$ in diameter: $25.4 \%(22.4 \%$ to $28.3 \%)(p<0 \cdot 005)$.

Table 2 Mean (95\% CI) for differences between Ventstream and Hudson nebulisers for area under the curve from 0 to 240 minutes after $5.0 \mathrm{mg}$ nebulised salbutamol for airways and systemic parameters

\begin{tabular}{|c|c|c|}
\hline & Mean $(95 \% C I)$ & $p$ \\
\hline $\begin{array}{l}\text { Airways responses } \\
\mathrm{FEV}_{1}(1 . \mathrm{min}) \\
\mathrm{FEF}_{25-75}\left(1 \times 10^{2}\right) \\
\mathrm{FVC}(1 . \mathrm{min}) \\
\text { PEFR }\left(1 \times 10^{2}\right)\end{array}$ & $\begin{array}{l}22.93(-16.09 \text { to } 61.95) \\
20.46(-11.58 \text { to } 52.50) \\
20.28(-10.87 \text { to } 51.43) \\
74.16(39.50 \text { to } 108.82)\end{array}$ & $\begin{array}{l}0 \cdot 2 \\
0 \cdot 1 \\
0 \cdot 1 \\
0 \cdot 001\end{array}$ \\
\hline $\begin{array}{l}\text { Systemic responses } \\
\text { Potassium (mmol/l.min) } \\
\text { Heart rate (beats) } \\
\text { Finger tremor (log units.min) } \\
\text { T wave }(\mathrm{mV} . \mathrm{min}) \\
\text { Q-Tc }\left(\mathrm{ms}^{2} \times 10^{3}\right)\end{array}$ & $\begin{array}{l}42 \cdot 54(-1.62 \text { to } 86 \cdot 7) \\
1680(609 \text { to } 2751) \\
48 \cdot 79(7.35 \text { to } 90 \cdot 23) \\
9 \cdot 3(-4 \cdot 0 \text { to } 22 \cdot 6) \\
45 \cdot 4(-9.9 \text { to } 100 \cdot 7)\end{array}$ & $\begin{array}{r}0.05 \\
<0.01 \\
<0.05 \\
0.1 \\
<0.01\end{array}$ \\
\hline
\end{tabular}

$\mathrm{FEV},=$ forced expiratory volume in one second; $\mathrm{FEF}_{25-75}=$ found expiratory flow rate at $25-75 \%$ of vital capacity; FVC = forced vital capacity; $P E F R=$ peak expiratory flow rate
PHARMACOKINETICS (table 1, fig 3)

The Ventstream produced significantly greater plasma salbutamol concentrations than the Hudson at each dose and for up to four hours after the last dose $(p<0.01)$. This was reflected in the $\mathrm{C}_{\max }$ and $\mathrm{AUC}_{0-240}$ which showed approximately twofold differences between the two nebulisers, the $95 \% \mathrm{CI}$ for the difference in $\mathrm{AUC}_{0-240}$ at the $5.0 \mathrm{mg}$ dose being 392.1 $(240.6$ to 543.6$) \mathrm{ng} / \mathrm{ml}$.min $(\mathrm{p}<0.001)$. Significant $(\mathrm{p}<0.05)$ differences in $\mathrm{C}_{\max }$ values occurred between the three doses for each nebuliser but no significant differences were seen in $t_{\max }$ between the two delivery systems.

\section{PHARMACODYNAMIC EFFECTS}

No significant differences between baseline values were found for any of the airways or systemic parameters measured (figs 4 and 5).

\section{Systemic responses}

(i) Absolute response (fig 4): no significant differences between the two nebulisers were seen at the $1.25 \mathrm{mg}$ dose. There were significantly greater effects with the Ventstream nebuliser than the Hudson at the $2.5 \mathrm{mg}$ dose for serum potassium concentrations $(95 \% \mathrm{CI}$ for difference) $0.25(0.01$ to 0.49$) \mathrm{mmol} / \mathrm{l}$ $(p<0.05)$ and for heart rate 5 ( 1 to 9$)$ beats/ min $(p<0.05)$. At the $5.0 \mathrm{mg}$ dose significantly greater effects were seen with the Ventstream for serum potassium concentration: $0.30(0.04$ to 0.56$) \mathrm{mmol} / 1(\mathrm{p}<0.05)$, heart rate 12 (4 to 20) beats/min $(\mathrm{p}<0.01)$, finger tremor: 0.24 $(0.05$ to 0.43$) \log$ units $(\mathrm{p}<0.05)$, and for $\mathrm{T}$ wave response: $0.06(0.02$ to 0.10$) \mathrm{mV}$, $(p<0 \cdot 05)$. No significant differences were found for Q-Tc at any dose. There was also a significantly greater $\mathrm{AUC}_{0-240}$ with the Ventstream nebuliser for heart rate $(\mathrm{p}<0.01)$ and finger tremor $(\mathrm{p}<0.05)($ table 2$)$.

Table 3 Mean (95\% CI) changes from baseline values of airways and systemic responses at $30 \mathrm{minutes}$ after $1 \cdot 25 \mathrm{mg}, 2 \cdot 5 \mathrm{mg}$, and $5 \cdot 0 \mathrm{mg}$ for each nebuliser

\begin{tabular}{|c|c|c|c|c|}
\hline & & $1.25 \mathrm{mg}$ & $2 \cdot 5 \mathrm{mg}$ & $5.0 \mathrm{mg}$ \\
\hline $\begin{array}{l}\text { Airways responses } \\
\mathrm{FEV}_{1}(1)\end{array}$ & $\begin{array}{l}\mathrm{V} \\
\mathrm{H}\end{array}$ & $\begin{array}{l}0.79(0.63 \text { to } 0.95) \\
0.69(0.53 \text { to } 0.85)\end{array}$ & $\begin{array}{l}0.89(0.77 \text { to } 1.01) \dagger \\
0.86(0.74 \text { to } 0.98) \dagger\end{array}$ & $\begin{array}{l}1.00(0.88 \text { to } 1.12)^{*} \\
0.93(0.81 \text { to } 1.05)\end{array}$ \\
\hline $\mathrm{FEF}_{25-75}(1 / \mathrm{s})$ & $\begin{array}{l}\mathrm{V} \\
\mathrm{H}\end{array}$ & $\begin{array}{l}0.72(0.47 \text { to } 0.97) \\
0.53(0.28 \text { to } 0.78)\end{array}$ & $\begin{array}{l}0.70(0.53 \text { to } 0.87) \\
0.73(0.56 \text { to } 0.90) \dagger\end{array}$ & $\begin{array}{l}0.96(0.79 \text { to } 1.13)^{*} \\
0.77(0.60 \text { to } 0.94)\end{array}$ \\
\hline $\mathrm{FVC}(1)$ & $\begin{array}{l}\mathrm{V} \\
\mathrm{H}\end{array}$ & $\begin{array}{l}0.88(0.62 \text { to } 1.14) \\
0.86(0.60 \text { to } 1.12)\end{array}$ & $\begin{array}{l}1.12(0.90 \text { to } 1.34) \dagger \\
1.03(0.82 \text { to } 1.24) \dagger\end{array}$ & $\begin{array}{l}1.18(0.94 \text { to } 1.42) \\
1.12(0.89 \text { to } 1.35)\end{array}$ \\
\hline PEFR (1/min) & $\begin{array}{l}\mathrm{V} \\
\mathrm{H}\end{array}$ & $\begin{array}{l}146(74 \text { to } 220) \\
133(61 \text { to } 205)\end{array}$ & $\begin{array}{l}162(92 \text { to } 232) \\
150(79 \text { to } 221)\end{array}$ & $\begin{array}{l}167(89 \text { to } 245) \\
162(83 \text { to } 241)\end{array}$ \\
\hline $\begin{array}{l}\text { Systemic responses } \\
\text { Potassium (mmol/l) }\end{array}$ & $\begin{array}{l}\mathrm{V} \\
\mathrm{H}\end{array}$ & $\begin{array}{c}0(-0.11 \text { to } 0.11) \\
0.04(-0.02 \text { to } 0.10)\end{array}$ & $\begin{array}{c}-0.06(-0.17 \text { to } 0.05) \\
0.10(0.04 \text { to } 0.16)\end{array}$ & $\begin{array}{l}-0.23(-0.34 \text { to }-0.12)^{*} \\
-0.02(-0.08 \text { to } 0.04)^{*}\end{array}$ \\
\hline Heart rate (beats/min) & $\begin{array}{l}\mathrm{V} \\
\mathrm{H}\end{array}$ & $\begin{array}{l}-3(-7 \text { to } 1) \\
-2(-3 \text { to }-1)\end{array}$ & $\begin{array}{r}-1(-5 \text { to } 3) \\
0(-2 \text { to } 2)\end{array}$ & $\begin{array}{ll}6 & (2 \text { to } 10)^{*} \\
0 & (-2 \text { to } 2)\end{array}$ \\
\hline Finger tremor (log units) & $\begin{array}{l}\mathrm{V} \\
\mathrm{H}\end{array}$ & $\begin{array}{l}0.15(0.02 \text { to } 0.28) \\
0.06(-0.07 \text { to } 0.19)\end{array}$ & $\begin{array}{l}0.29(0.16 \text { to } 0.42) \\
0.19(0.06 \text { to } 0.32)\end{array}$ & $\begin{array}{l}0.49(0.36 \text { to } 0.62)^{*} \\
0.34(0.21 \text { to } 0.47)\end{array}$ \\
\hline $\mathrm{Q}-\mathrm{Tc}(\mathrm{ms})$ & $\begin{array}{l}\mathrm{V} \\
\mathrm{H}\end{array}$ & $\begin{array}{l}-6(-16 \text { to } 4) \\
-2(-8 \text { to } 4)\end{array}$ & $\begin{array}{l}3(-7 \text { to } 13) \\
2(-4 \text { to } 8)\end{array}$ & $\begin{array}{r}13 \quad(3 \text { to } 23) \\
6 \quad(0 \text { to } 12)\end{array}$ \\
\hline $\mathrm{T}$ wave $(\mathrm{mV})$ & $\begin{array}{l}\mathrm{V} \\
\mathrm{H}\end{array}$ & $\begin{array}{r}0.01(-0.005 \text { to } 0.03) \\
-0.01(-0.03 \text { to } 0.01)\end{array}$ & $\begin{array}{l}0.03(0.01 \text { to } 0.05) \\
0.01(-0.01 \text { to } 0.03)\end{array}$ & $\begin{array}{l}0.06(0.04 \text { to } 0.08)^{*} \\
0.03(0.01 \text { to } 0.05)\end{array}$ \\
\hline
\end{tabular}

$\mathrm{V}=$ Ventstream; $\mathrm{H}=$ Hudson; $\mathrm{FEV}_{1}=$ forced expiratory volume in one second; $\mathrm{FEF}_{25-75}=$ forced expiratory flow rate at $25-75 \%$ of vital capacity; $\mathrm{FVC}=$ forced vital

${ }^{*} \mathrm{p}<0.05,2.5 \mathrm{mg} v 5 \mathrm{mg}$ for each nebuliser; $\dagger \mathrm{p}<0.05,1.25 \mathrm{mg} v 2.5 \mathrm{mg}$ for each nebuliser. 
(ii) Delta response (table 3): There were no significant differences between the $1.25 \mathrm{mg}$ and $2.5 \mathrm{mg}$ doses for either nebuliser. There were significant differences $(p<0.05)$ between the $2.5 \mathrm{mg}$ and $5.0 \mathrm{mg}$ doses for all systemic responses except for Q-Tc when using the Ventstream, and a significant $(\mathrm{p}<0.05)$ difference in serum potassium concentration occurred between $2.5 \mathrm{mg}$ and $5 \mathrm{mg}$ doses with the Hudson nebuliser.

\section{AIRWAYS RESPONSES}

(i) Absolute response (fig 5): there were no significant differences in absolute values for airways responses between the two nebulisers at any of the three doses, irrespective of the parameter measured. The $\mathrm{FEV}_{1}$ response to the $1.25 \mathrm{mg}$ dose was approaching the plateau in the dose-response curve, although even at the $5.0 \mathrm{mg}$ dose the mean $\mathrm{FEV}_{1}$, when calculated as $\%$ predicted (mean and $95 \% \mathrm{CI}$ ) was only $78 \cdot 3 \%(74.4 \%$ to $82 \cdot 1 \%)$ for the Ventstream, and $76 \cdot 0 \%(72 \cdot 1 \%$ to $79.9 \%)$ for the Hudson. A significantly $(p<0.001)$ greater AUC $_{0-240}$ was demonstrated with the Ventstream for PEFR.

(ii) Delta response (table 3): there were significant $(p<0.05)$ differences in delta $\mathrm{FEV}_{1}$ between all three doses with the Ventstream, but with the Hudson nebuliser there was only a significant $(\mathrm{p}<0.05)$ difference in delta $\mathrm{FEV}_{1}$ between the $2.5 \mathrm{mg}$ and $1.25 \mathrm{mg}$ doses. For $\mathrm{FEF}_{25-75}$ the top of the dose-response curve occurred at $5.0 \mathrm{mg}$ for the Ventstream and at $2.5 \mathrm{mg}$ with the Hudson. For delta FVC there was no significant improvement over and above the $2.5 \mathrm{mg}$ response with either nebuliser. No significant differences in delta PEFR values were seen between the three doses irrespective of the nebuliser used.

\section{Discussion}

The results of this study have shown that the Ventstream nebuliser delivery system produced a twofold increase in delivery of salbutamol to the lung with associated greater systemic $\beta_{2}$ responses. There were also differences in the dose-response relationship for $\mathrm{FEV}_{1}$ and $\mathrm{FEF}_{25}$, and a greater PEFR response in terms of AUC $_{(12,1)}$. As a consequence of improved delivery it may be possible to halve the drug dose to produce similar bronchodilator efficacy with reduced cost. In this respect the Ventstream nebuliser may be of more value for nebulising drugs such as corticosteroids and antibiotics, where optimisation of lung delivery is more important.

The improved drug delivery to the lung with the Ventstream nebuliser can be explained by considering the in vitro data which showed a greater aerosol output with the Ventstream than with the Hudson, as well as a greater percentage volume of particles with a diameter less than $5 \mu \mathrm{m}$. The matching of aerosol output to tidal volume during inspiration would significantly increase the total dose of salbutamol delivered to the lungs when using the Ventstream nebu- liser. Furthermore, it is known that aerosol deposition within the lungs is dependent upon the size of the particles ${ }^{1510}$ which varies according to the nebuliser type and the driving flow rate. ${ }^{17}{ }^{19}$ Indeed, it has been shown that particles smaller than $5 \mu \mathrm{m}$ in diameter penetrate to the peripheral airways by virtue of the fact that they avoid deposition by impaction in the oropharynx or more central airways. ${ }^{21}$ In this respect the significantly greater percentage volume of particles with optimal diameter using the Ventstream, in combination with matching output to tidal volume, would tend to increase aerosol delivery to the alveoli which is known to be the major site for systemic absorption of salbutamol. ${ }^{21} 24$ The pharmacokinetic profile with a $t_{\max }$ of 5-10 minutes would also point towards systemic absorption occurring primarily from the lung rather than from the gut. Since the Ventstream does not increase oral deposition, the pharmacokinetic differences between the two nebulisers are therefore likely to be due to enhanced lung delivery and resulting increased bioavailability from the pulmonary vascular bed. It is also worth pointing out that the differences in particle size between the two nebulisers are thought to be due to their different internal design configurations, rather than the variation in airflow rates.

The enhanced systemic absorption of salbutamol with the Ventstream was associated with significantly greater extrapulmonary effects, although this was only seen at the $2.5 \mathrm{mg}$ and $5.0 \mathrm{mg}$ doses. This may be because the dose-response curve for the systemic effects becomes steep after the $1.25 \mathrm{mg}$ dose, in contrast to the airways responses where the curve is relatively flat above this dose. This phenomenon has been described previously with metered dose aerosols evaluated over a similar dose range in asthmatic subjects. ${ }^{2526}$ It is worth pointing out, however, that the mean maximal difference in delta response between the two nebulisers was only $0.21 \mathrm{mmol} / 1$ for serum potassium concentration, 6 beats/min for heart rate, and $7 \mathrm{~ms}$ for $\mathrm{Q}-\mathrm{Tc}$; these differences are not likely to be of any relevance in terms of arrhythmogenic potential. This is also reflected in the magnitude of the absolute values (peak heart rate of 80 beats/min, nadir serum potassium concentration of $3.5 \mathrm{mmol} / \mathrm{l}$, and Q-Tc of $397 \mathrm{~ms}$ with the Ventstream) which are of little clinical relevance. Furthermore, it has been shown with radiolabelled aerosol deposition that increasing airways obstruction significantly reduces the peripheral lung deposition of inhaled aerosols, with a greater propensity for deposition to occur in large, central airways. ${ }^{27}{ }^{29}$ In patients with severe airflow obstruction, who are likely to require nebulised $\beta_{2}$ agonists frequently, the magnitude of systemic responses would therefore be even less as a result of reduced alveolar access for inhaled particles.

No significant differences were found between the two nebulisers for the peak bronchodilator response; this may be explained by three factors. Firstly, the $1.25 \mathrm{mg}$ dose produced a bronchodilator response which was approaching the top of the dose-response curve 
in the patients studied who had asthma of moderate severity. In this respect the top of the dose-response curve was the result of patients bronchodilating to their own maximal achievable response, rather than reaching their predicted normal values, as even at the $5.0 \mathrm{mg}$ dose the $\mathrm{FEV}_{1}$ was less than $80 \%$ predicted normal with both nebulisers. It is conceivable that the Ventstream might produce a larger airways response at lower doses which lie on the steep part of the dose-response curve in patients with mild to moderate asthma. It is important to point out, however, that in patients with more severe airflow obstruction the Ventstream nebuliser may produce a greater bronchodilator response within the dose range $1 \cdot 25-5 \cdot 0 \mathrm{mg}$ since higher doses are required to reach the steep part of the dose-response curve in such patients. It may not be possible, therefore, to extrapolate the results of the present study to a different patient population who have more severe airflow obstruction.

Secondly, the statistical power of the study ( $80 \%$ with $20 \% \beta$ error) was calculated on the basis of serum potassium levels being the primary end point. Estimations from power calculations, ${ }^{30}$ however, have shown that at least 12 subjects are required to detect a $15 \%$ difference in $\mathrm{FEV}_{1}$ in order to exceed natural variability in $F E V_{1}$ values. Hence, with a sample size of eight patients the statistical power may not have been sufficient to detect significant differences in peak airways response between the two nebulisers.

Thirdly, it is unclear whether improved aerosol delivery to the peripheral lung has a significant effect on the bronchodilator response to inhaled $\beta_{2}$ agonist. In a previous study comparing lung deposition and $\mathrm{FEV}_{1}$ in patients with moderately severe asthma, bronchodilator responses were equivalent following inhalation of radiolabelled terbutaline aerosol containing small (mass median diameter $1.5 \mu \mathrm{m}$ ) and large (mass median diameter $4.8 \mu \mathrm{m}$ ) particles, despite heavy central deposition when using the latter. $^{3}$ Furthermore, in another study deposition in the lung periphery was significantly improved following inhalation of a single $200 \mu \mathrm{g}$ dose of salbutamol when using a spacer compared with a metered dose inhalation alone, whereas $\mathrm{FEV}_{1}$ response as a percentage change from baseline was not significantly different. ${ }^{31}$ Significant improvements in $\mathrm{FEF}_{50}$ and $\mathrm{FEF}_{75}$ (but not in $\mathrm{FEV}_{1}$ ) have been seen, however, following a $2.5 \mathrm{mg}$ dose of nebulised terbutaline aerosol with a mass median diameter of $1.8 \mu \mathrm{m}$ compared with aerosols with mass median diameters of $4.6 \mu \mathrm{m}$ and $10.3 \mu \mathrm{m}$ respectively. ${ }^{32}$ Furthermore, Johnson et $a l^{2}$ found a significant left shift in the DRC to salbutamol (250-2000 $\mu \mathrm{g})$ when nebulisers with mass median diameters of $3.3 \mu \mathrm{m}$ and $7 \cdot 7 \mu \mathrm{m}$ were compared.

It is important to point out that, although no differences were found in the peak bronchodilator responses between the two nebulisers, there was evidence to suggest that the airways dose-response was steeper with the Ventstream nebuliser than with the Hudson as the maximum response for $\mathrm{FEV}_{1}$ and $\mathrm{FEF}_{25-75}$ was achieved at the $5.0 \mathrm{mg}$ dose with the Ventstream and at the $2.5 \mathrm{mg}$ dose with the Hudson. Furthermore, there was a trend towards higher values for all parameters at four hours after the final dose and, indeed, a significant difference in the $A C_{0-240}$ for PEFR was seen. In this respect the $\mathrm{AUC}_{0.240}$ may be a better reflection of the overall response to the inhaled $\beta_{2}$ agonist than the peak response. It is conceivable, therefore, that the improved $\mathrm{AUC}_{0240}$ for PEFR may reflect the improved drug delivery and indicate an increased duration of bronchodilator response when using the Ventstream nebuliser.

Further studies are indicated to fully investigate the bronchodilator response to lower doses of salbutamol and ipratropium bromide with the Ventstream nebuliser, and also to evaluate the lung deposition and efficacy of other drugs such as corticosteroids and antibiotics.

The authors thank Mrs J Orr for typing the manuscript, $\mathrm{Mr} \mathrm{G}$ Clark for the salbutamol assays, Mrs L McFarlane for the potassium assays, and Medic-Aid Ltd, UK, for their support of the study.

1 Lewis RA, Cushley MJ, Fleming JS, Tattersfield AE. Is a nebuliser less efficient than a metered dose inhaler and do pear shaped extension tubes work? Am Rcr Respir Dis 1982;125:94.

2 Johnson MA, Newman SP, Bloom R, Talaee N, Clarke SW. Delivery of albuterol and ipratropium bromide from two nebuliser systems in chronic stable asthma. Chist 1989; 96:6-10.

3 Hultquist C, Wollmar P, Eklundh G, Jonson B. Effect of inhaled terbutaline sulphate in relation to its deposition in the lungs. Pulm Pharmacol 1992;5:127-32.

4 Lane DG. Chronic persistent asthma: nebulisers and therapy additional to inhaled $\beta$-agonists and steroids. Respir $M e d$ 1991;5:359-63.

5 O'Driscoll BR. Home nebulised therapy - is it effective. Respir Med 1991;85:1-3.

6 Lipworth BJ, McDevitt DG. Dose-response relationships with bronchodilator drugs. In: Kuhlmann J, Wingender W, eds. Dose-response relationships of drugs. Munchen: Zuckschwerdt Verlag, 1990:119-25.

7 Lipworth BJ. Risks versus benefits of inhaled $\beta_{2}$-agonists in the management of asthma. Drug Safety' 1992;7:54-70.

8 Dennis JH, Stenton SC, Beach JR, Avery AJ, Walters EH, Hendrick DJ. Jet and ultrasonic nebuliser output: use of a new method for direct measurement of aerosol output. Thorax 1990;45:728-33.

9 American Thoracic Society. Standards for the diagnosis and care of patients with chronic obstructive pulmonary disease (COPD) and asthma. Am Rev Respir Dis 1987;136:225.

10 American Thoracic Society. Standardisation of spirometry - update. Am Rev Respir Dis 1987;136:1285-9.

1 Lipworth BJ, Clark RA, Dhillon DP, Moreland TA, Struthers AD, Clark GA, et al. Pharmacokinetics, efficacy and adverse effects of sublingual salbutamol in patients with asthma. Eur f Clin Pharmacol 1989;37:567-71.

12 Shamroth L. An introduction to electrocardiography. Oxford: Blackwell Scientific Publications, 1982:141-4.

13 Bazett HC. An analysis of the time relations of electrocardiograms. Heart 1920;7:353-70.

14 Lipworth BJ, McDevitt DG. Beta-adrenoceptor responses to inhaled salbutamol in normal subjects. Eur $\mathcal{f} \mathrm{Clin}$ Pharmacol 1989;36:239-45.

5 Brain JD, Valberg PA. Deposition of aerosol in the respiratory tract. Am Rev Respir Dis 1979;20:1325-73.

16 Swift DL. Generation and respiratory deposition of therapeutic aerosols. Am Rev Respir Dis 1980;122:71-7.

17 Clay MM, Pavia D, Newman SP, Clarke SW Factors influencing the size distribution of acrosols from jet influencing the size distribution
nebulisers. Thorax 1983;38:755-9.

18 Sterk PJ, Plomp A, Van de Vate JF, Quanjer PH. Physical properties of aerosols produced by several jet and ultrasonic nebulisers. Bull Eur Physiopathol Respir 1984;20: 65-72.

9 Newman SP, Pellow PGD, Clark SW. Droplet size distributions of nebulised aerosols for inhalation therapy. C/in Phys Physiol Meas 1986;7:139-46.

20 Gerrity TR, Lees PS, Haas FJ, Marinelli A, Werner P, Lowenco RV. Calculated deposition of inhaled particles in the airway generations of normal subjects. 7 Appl Plyviol 1979;47:867-73.

21 Kung M, Croley SW, Phillips BA. Systemic cardiovascular and metabolic effects associated with the inhalation of an increased dose of albuterol; influence of mouth rinsing increased dose of albuterol; influence of mouth rinsing

22 Collier JG, Dobbs RJ, Williams I. Salbutamol acrosol causes a tachycardia due to the inhaled rather than the swallowed fraction. Br f Clin Pharmacol 1980;9:273-4. 
23 Lipworth BJ, McDevitt DG, Struthers AD. Systemic betares dose inhaler alone and with pear-shaped spacer attachment: comparison of electrocardiographic, hypoattachment. Comparison of electrocardiographic, hypo1989;27:837-42.

24 Newnham DM, McDevitt DG, Lipworth BJ. Comparison of the extrapulmonary $\beta_{\text {,-adrenoceptor responses and }}$ pharmacokinetics of salbutamol given by standard metere dose inhaler and modified actuator device. $\mathrm{Br} \mathcal{J} \mathrm{Clin}$ Pharmacol 1993;36:445-50.

25 Larsson S, Svedmyr N. Bronchodilating effect and side effects of beta-2 adrenoceptor stimulants by differen modes of administration (tablets, metered aerosol and combinations thereof). Am Rev Respir Dis 1977;116:861-8.

26 Lipworth BJ, Clark RA, Dhillon DP, Brown RA, McDevitt DG. Beta-adrenoceptor responses to high doses of inhaled salbutamol in patients with bronchial asthma. Br $\mathrm{f}$ Clin Pharmacol 1988;26:527-33.
27 Chopra SK, Taplin GV, Tashkin DP. Imaging sites of airway obstruction and measuring functional responses to bronchodilator treatment in asthma. Thorax 1979:34:493-500.

28 Itoh $\mathrm{H}$, Ishii $\mathrm{Y}$, Maeda $\mathrm{H}$, Todo G, Torizuka L, Smaldone $\mathrm{G}$. Clinical observations of aerosol deposition in patients with airways obstruction. Chest $1981 ; 80$ (Suppl):837-40.

29 Laube BL, Swift DL, Wagner Jr HN, Norman PS, Adams III GK. The effect of bronchial obstruction on central airway deposition of a saline aerosol in patients with asthma. Am Rev Respir Dis 1986;133:740-3.

30 Altman DG. Statistics and ethics in medical research: how large a sample? BMF 1980;281:1336-8.

31 Melchor R, Biddiscombe MF, Mak VHF, Short MD, Spiro SG. Lung deposition patterns of directly labelled salbutamol in normal subjects and in patients with reversible airflow obstruction. Thorax 1993;48:506-11.

32 Clay MM, Pavia D, Clarke SW. Effect of aerosol particle size on bronchodilatation with nebulised terbutaline in asthmatic subjects. Thorax 1986;41:364-8. 